\title{
POTENTIAL HAZARDS FROM FLOODFLOWS WITHIN THE JOHN MUIR HOUSE NATIONAL HISTORIC SITE, FRANKLIN CREEK DRAINAGE BASIN, CALIFORNIA
}

By Robert W. Meyer

U.S. GEOLOGICAL SURVEY

Water-Resources Investigations Report 93-4009

Prepared in cooperation with the

NATIONAL PARK SERVICE

$\frac{\text { }}{\text { จे }}$ 


\section{U.S. DEPARTMENT OF THE INTERIOR BRUCE BABBITT, Secretary}

U.S. GEOLOGICAL SURVEY

ROBERT M. HIRSCH, Acting Director

Any use of trade, product, or firm names in this publication is for descriptive purposes only and does not imply endorsement by the U.S. Government.

For sale by the

U.S. Geological Survey

Earth Science Information Center

Open-File Reports Section

Box 25236, MS 517

Denver Federal Center

Denver, CO 80225

For additional information write to:

District Chief

U.S. Geological Survey

Federal Building, Room W-2233

2800 Cottage Way

Sacramento, CA 95825 


\title{
CONTENTS
}

\author{
Abstract 1 \\ Introduction 1 \\ Description of drainage basin 1 \\ Flood hydrology 4 \\ Maximum floodflows in California 7 \\ Potential hazards from floodflows at Franklin Creek 8 \\ Summary 9 \\ References cited 9
}

\section{FIGURES}

1-2. Maps showing location of:

1. John Muir House National Historic Site and Franklin Creek drainage basin 2

2. Surveyed cross sections and details of the John Muir House National Historic Site 3

3. Graph showing water-surface elevations for selected recurrence interval 4

4. Surveyed cross sections showing water-surface elevation for the 100 -year recurrence interval flood 5

5. Graph showing selected peak discharges and regional envelope curve $\mathbf{8}$

6. Map showing area of highest recorded peak flows used to estimate $Q_{m e} \quad 8$

\section{TABLES}

1. Elevation of thalweg and top of bank 4

2. Estimated water-surface elevations for each cross section $\mathbf{6}$

3. Flow magnitude and probability of exceedance for selected recurrence intervals 7

\section{Conversion Factors and Vertical Datum}

\section{Conversion Factors}

\begin{tabular}{rcl}
\hline Multiply & By & To obtain \\
\hline cubic foot per second $\left(\mathrm{ft}^{3} / \mathrm{s}\right)$ & 0.0283 & cubic meter per second \\
foot $(\mathrm{ft})$ & 0.3048 & meter \\
inch $(\mathrm{in})$. & 25.4 & millimeter \\
mile $(\mathrm{mi})$ & 1.609 & kilometer \\
square mile $\left(\mathrm{mi}^{2}\right)$ & 2.590 & square kilometer \\
\hline
\end{tabular}

\section{Vertical Datum}

Sea level: In this report, "sea level" refers to the National Geodetic Vertical Datum of 1929-a geodetic datum derived from a general adjustment of the first-order level nets of the United States and Canada, formerly called Sea Level Datum of 1929. 


\title{
POTENTIAL HAZARDS FROM FLOODFLOWS WITHIN THE JOHN MUIR HOUSE NATIONAL HISTORIC SITE, FRANKLIN CREEK DRAINAGE BASIN, CALIFORNIA
}

\author{
By Robert W. Meyer
}

\begin{abstract}
To assist the National Park Service in management decisionmaking, the Franklin Creek drainage basin of California was studied to determine flood-hazard potentials within the boundaries of the John Muir House National Historic Site. The drainage-area-ratio method, adjusted by multiple regression coefficients, was used to determine flood magnitudes of specific recurrence intervals. Water-surface elevations and inundation areas were determined using hydraulic equations that assume uniform flow and that channel geometry would remain as surveyed in the 1984 water year.
\end{abstract}

Franklin Creek is expected to overflow its banks during all floods greater than the 25-year flood. Maximum flood discharges within the Historic Site boundaries are limited by the large culvert that conveys floodwaters into the site. The historically significant structures were constructed above the flood elevation for the 100year flood; therefore, with the exception of the carriage house, there is little or no danger to the irreplaceable structures at the site. The carriage house could be inundated several feet by the 100-year flood.

\section{INTRODUCTION}

The John Muir House National Historic Site in California was set aside in 1964 as a memorial to John Muir for his efforts in conservation and his advocacy of the establishment of national parks. The site, located in the drainage basin of Franklin Creek, includes Muir House, the Martinez Adobe, a carriage house, several acres of orchards and vineyards, and a visitor's center (figs. 1 and 2).
Because of the proximity of Franklin Creek channel to the Historic Site and the potential of flooding that could affect visitor safety and the cultural and natural resources at the site, the U.S. Geological Survey, in cooperation with the National Park Service, studied the flood-hazard potential in the Franklin Creek drainage basin within the boundaries of the Historic Site. Additional hydrologic analysis outside the site was necessary to analyze the floodhazard potential within the confines of the site (fig. $2)$. The scope of the study included selecting and surveying 26 cross sections along the Franklin Creek channel, plotting profiles of water-surface elevations, and compiling various types of hydrologic data. This report provides an explanation of the methods used, summarizes potential flood hazards, and delineates areas on the site at risk from floods of various recurrence intervals.

\section{DESCRIPTION OF DRAINAGE BASIN}

The John Muir House National Historic Site is in the drainage basin of Franklin Creek. The site is adjacent to the southwestern boundary of the city of Martinez in Contra Costa County, California. The Carquinez Strait is $2.5 \mathrm{mi}$ north of the site and San Pablo Bay is $7 \mathrm{mi}$ northwest. There is very little development other than roads and a railroad right-ofway in the drainage basin (fig. 1).

Elevations in the drainage basin range from 78 to $1,040 \mathrm{ft}$ above sea level at the southwestern basin divide, which is the Franklin Ridge. The Franklin Creek drainage basin trends from northwest to southeast and includes an area of $5.01 \mathrm{mi}^{2}$. The underlying geologic structures of the basin are mostly composed of greywacke sandstone, shale, and conglomerates. The site is on deep, loamy-clay soils developed from alluvial deposits of Franklin Creek. The upper reaches of the stream are in a state 


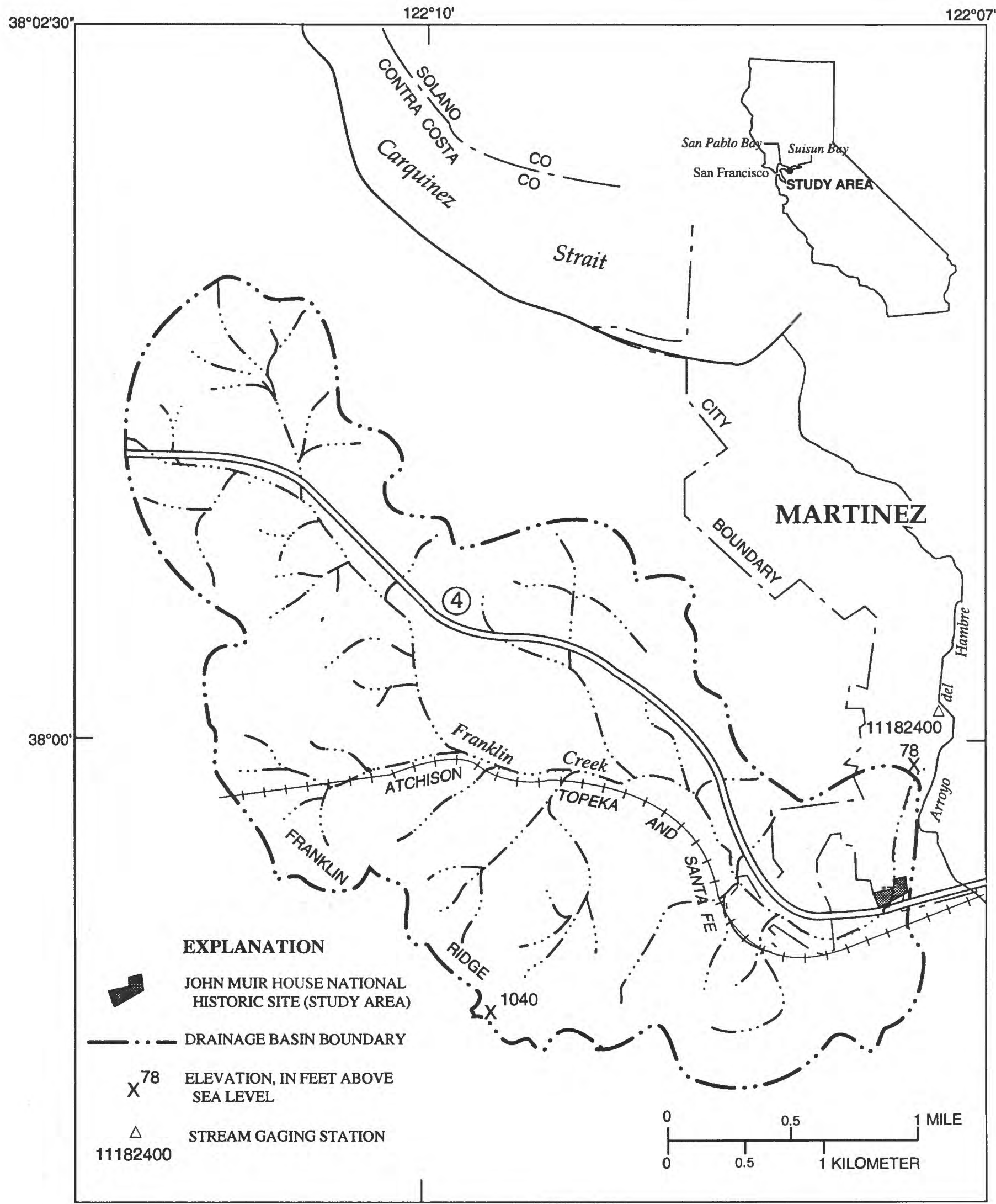

Figure 1. Location of John Muir House National Historic Site and the Franklin Creek drainage basin. 


\section{EXPLANATION}

POINT OF INTEREST

1 Muir House

2 Visitor Center

3 Carriage House

4 Windmill

5 Martinez Adobe

6 Shed

7 Bridge

8 Steel Gate

15 CROSS SECTION

-50 - LINE OF EQUAL INUNDATION FOR 25-, 50-, AND 100-YEAR FLOOD

$-Q_{m e}-$ LINE OF EQUAL INUNDATION FOR MAXIMUM FLOOD EXPERIENCE

BOUNDARY OF JOHN MUIR HOUSE NATIONAL HISTORIC SITE

102.5

BENCHMARK - Number is elevation in feet above sea level
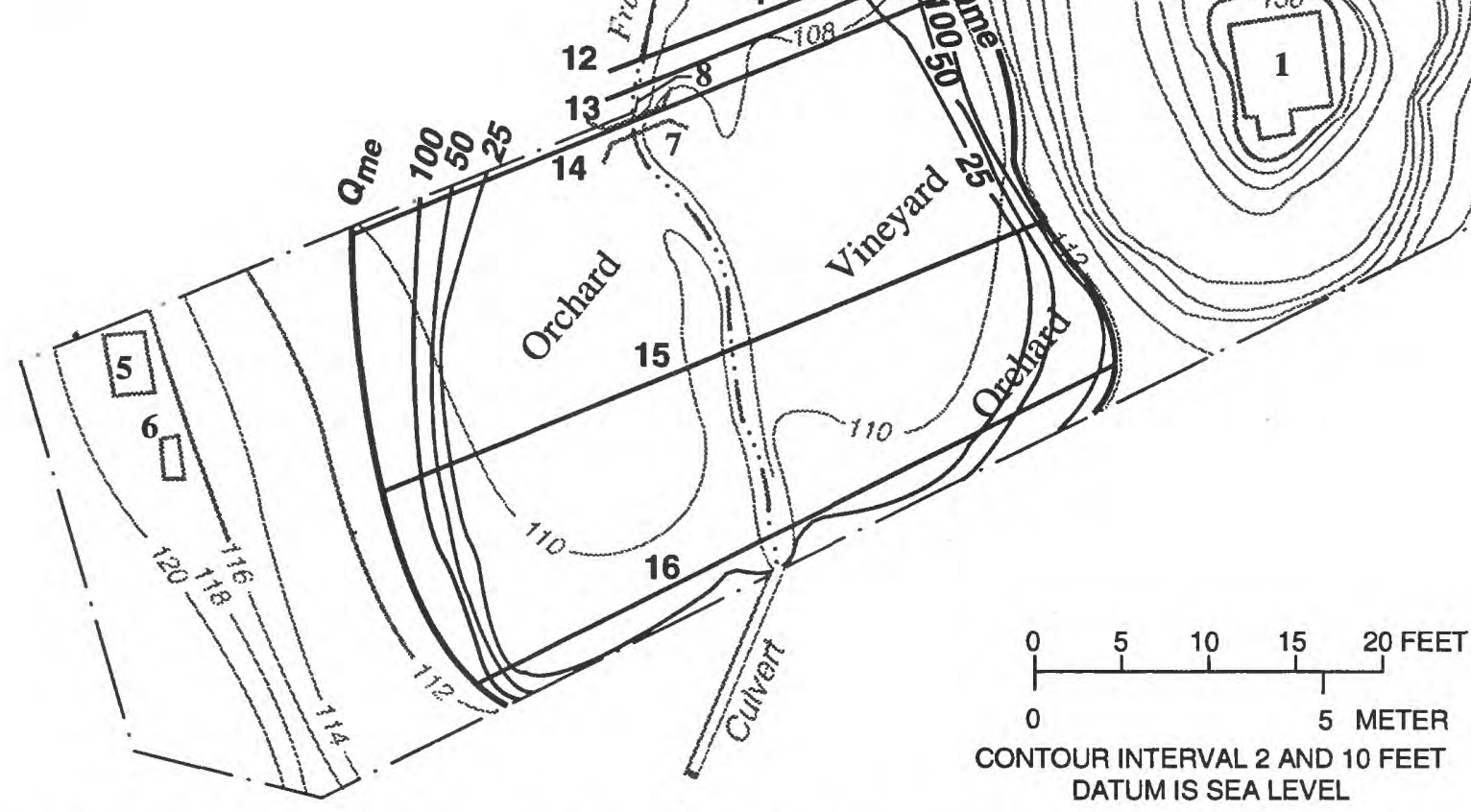

Figure 2. Location of surveyed cross sections and details of the John Muir House National Historic Site.

of dynamic equilibrium, showing little evidence of erosion.

The natural state of the channel has been extensively modified in the lower reaches (fig. 2). For
$1,400 \mathrm{ft}$ before entering the historic site, all flow is confined to a $10 \times 10$-foot concrete box culvert. Immediately downstream from the culvert outfall, berms confine the natural channel. The berms are not complete and do not extend throughout the site. Part 
of the channel has sandbagged banks, otherwise it is bare soil. Midway on its course through the site, there is a small single-span bridge. A steel gate is 10 $\mathrm{ft}$ downstream from the bridge and within the channel. Concrete banks extend downstream from the steel gate to the sharp $S$ turn in the channel. From the bend to the site boundary, the stream is essentially natural.

\section{FLOOD HYDROLOGY}

This study used the gaged as compared with ungaged drainage-area-ratio method, as described by Waananen and Crippen (1977). Discharges as determined using this method are larger than the regional equation discharges given by Waananen and Crippen (1977). Because discharges from the drainage-arearatio method exceeded the regional equation results, a verification was made with a unit-hydrograph analysis. Agreement between the hydrograph analysis and the drainage-area-ratio method was within 5 percent.

Data from the nearby stream-gaging station 11182400, Arroyo del Hambre at Martinez (about 0.8 mi north of the Historic Site), were used to estimate flood discharges. Franklin Creek is a major tributary of Arroyo del Hambre and the drainage basin area at the gaging station is $15.1 \mathrm{mi}^{2}$. A Log-Pearson type III computation was used to determine discharges for various recurrence intervals at the gaging station based on 11 years of peak flow records (Waananen and Crippen, 1977, table 5).

The computed peak discharges at the gaging station were adjusted for the difference in drainage area using the relation $Q_{u}=Q_{g}\left(A_{u} / A_{g}\right)^{b}$ where $Q_{u}$ and $Q_{g}$ are the discharges at the ungaged and gaged sites, $A_{u}$ and $A_{g}$ are the drainage areas, and $b$ is an exponent determined from regression analysis using data from the central and north coast regions. (The value of $b$ ranges from 0.88 for the 100 -year flood to 0.91 for the 5-year flood.) This method is explained in detail in Waananen and Crippen (1977).

Using discharges for the selected flood recurrence intervals, inundation boundaries were defined and are shown in figure 2. Water-surface profiles are shown in figure 3. Elevation data of the thalweg and top of bank for surveyed cross sections are given in table 1. Surveyed cross sections .within the site are shown with the water-surface elevation for the 100-year recurrence interval flood in figure 4 . Water-surface elevations for each cross section were calculated by conventional step-backwater procedures (table 2) (Shearman, 1977).

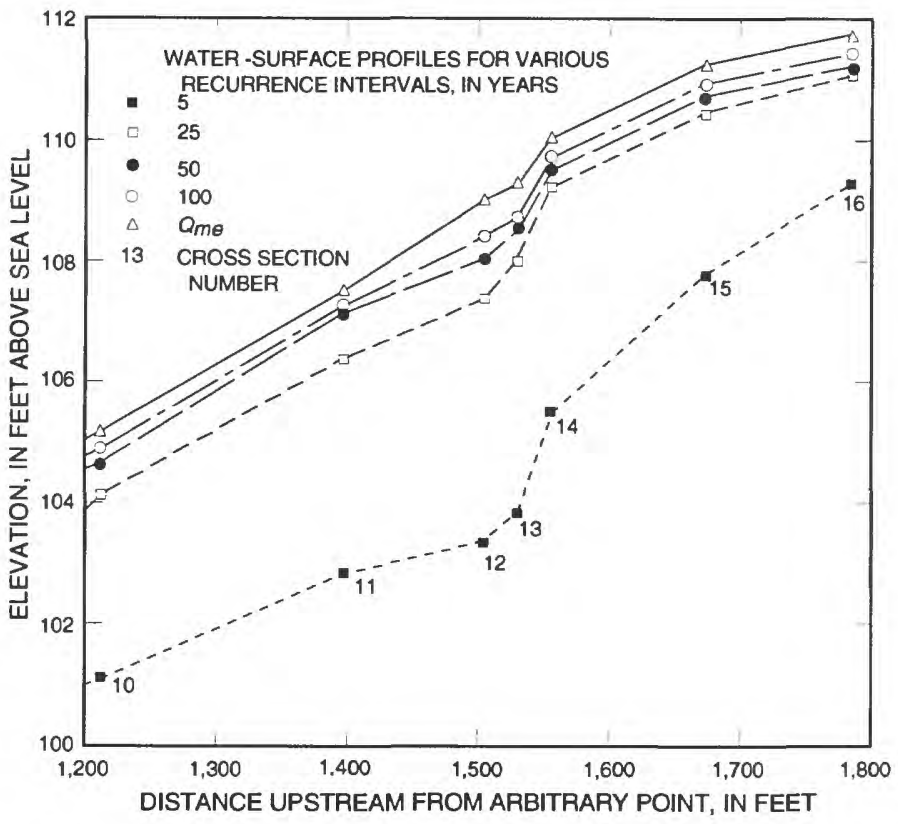

Figure 3. Water-surface elevations for selected recurrence intervals.

Table 1. Elevation of thalweg and top of bank

[Distance is upstream from arbitrary point (see fig. 3)]

\begin{tabular}{lcrlr}
\hline & & \multicolumn{3}{c}{$\begin{array}{c}\text { Elevation, in feet } \\
\text { above sea level }\end{array}$} \\
\cline { 4 - 5 } $\begin{array}{c}\text { Distance, } \\
\text { in feet }\end{array}$ & $\begin{array}{c}\text { Cross } \\
\text { section } \\
\text { (fig. 4) }\end{array}$ & Thalweg & \multicolumn{2}{c}{ Top of bank } \\
\cline { 3 - 5 } & & & Left & Right \\
\hline 1,213 & 10 & 93.9 & 104.9 & 104.2 \\
1,397 & 11 & 96.5 & 105.9 & 107.0 \\
1,505 & 12 & 97.2 & 106.7 & 107.5 \\
1,530 & 13 & 97.6 & 107.3 & 107.3 \\
1,555 & 14 & 101.6 & 108.3 & 109.2 \\
1,673 & 15 & 100.6 & 111.6 & 109.4 \\
1,785 & 16 & 104.7 & 110.9 & 112.5 \\
\hline
\end{tabular}

Water-surface elevations in table 2 are based on channel geometry as surveyed in the 1984 water year. As the probability of exceedance decreases (table 3 ), the uncertainty of computed water-surface elevations increases. This uncertainty is caused by the capability of larger floods to significantly modify the flood channel and flood plain by erosional and depositional processes, and by the uncertainty in estimates of lowprobability floods based on short periods of record, and by other factors. 


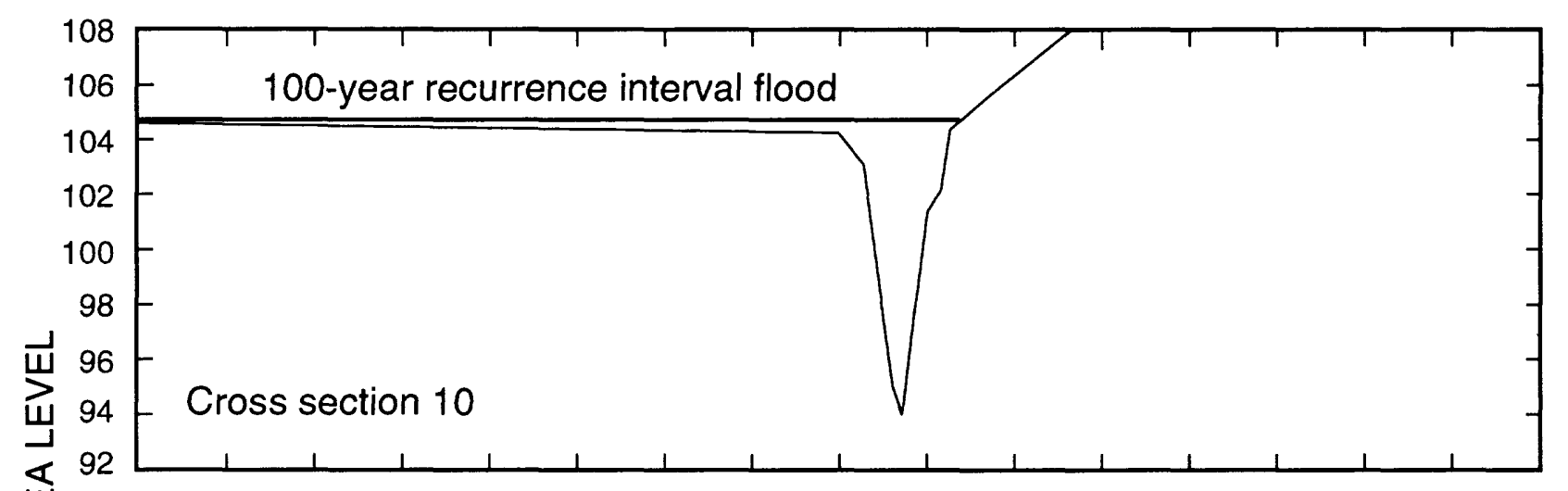

C 112

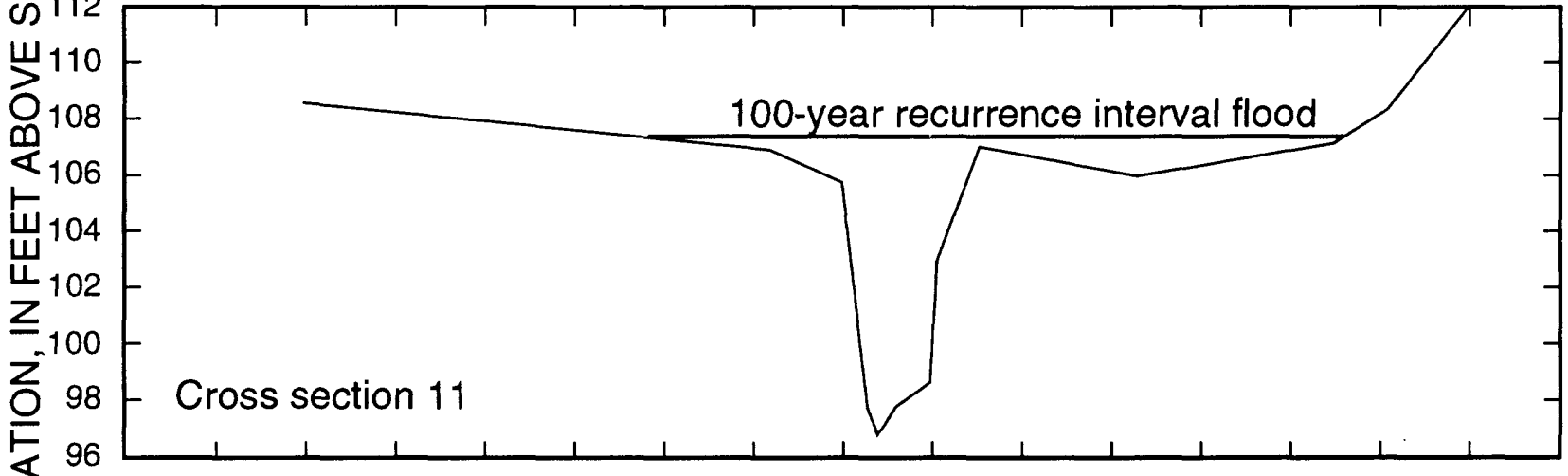

W 112

Ш110

(U) 108

난 106

$\overbrace{0}^{104}$

ณ́10

Ш 100

$\$ 98$

ค 96

แ

ש11

$\sum 110$

क 108

ш 106

104

102

100

98

96

Cross section 12

100-year recurrence interval flood

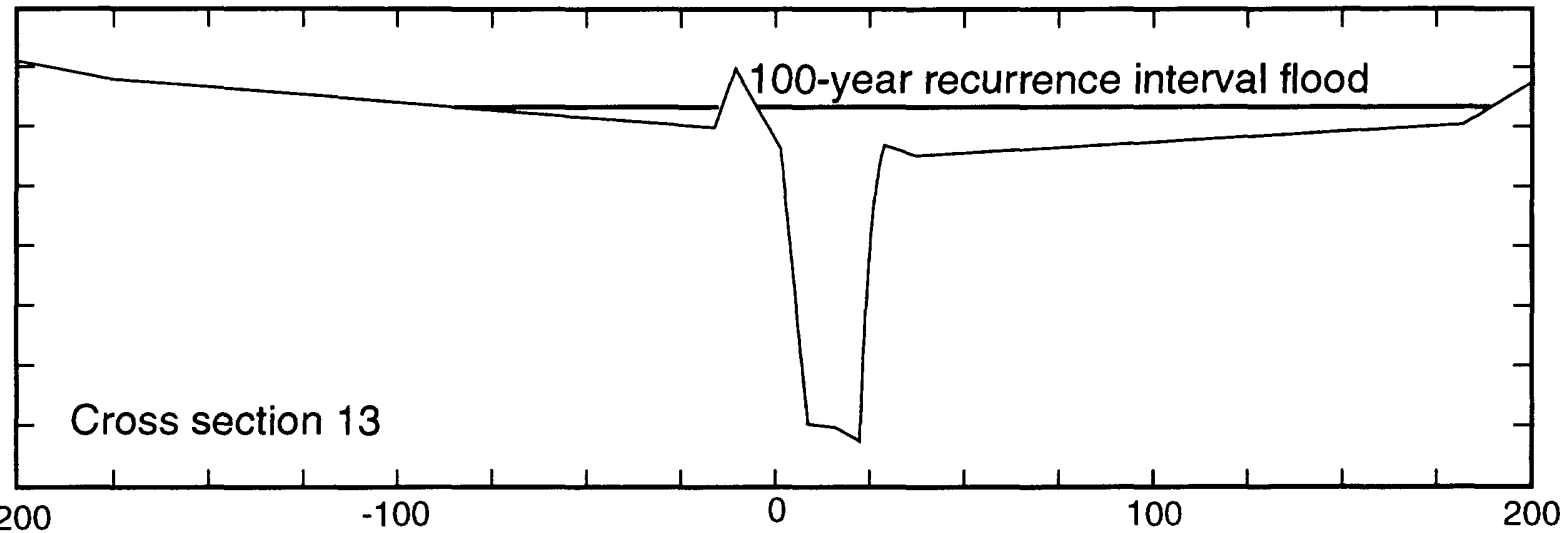

DISTANCE FROM ARBITRARY POINT, IN FEET

Figure 4. Surveyed cross sections showing water-surface elevation for the 100 -year recurrence interval flood. 


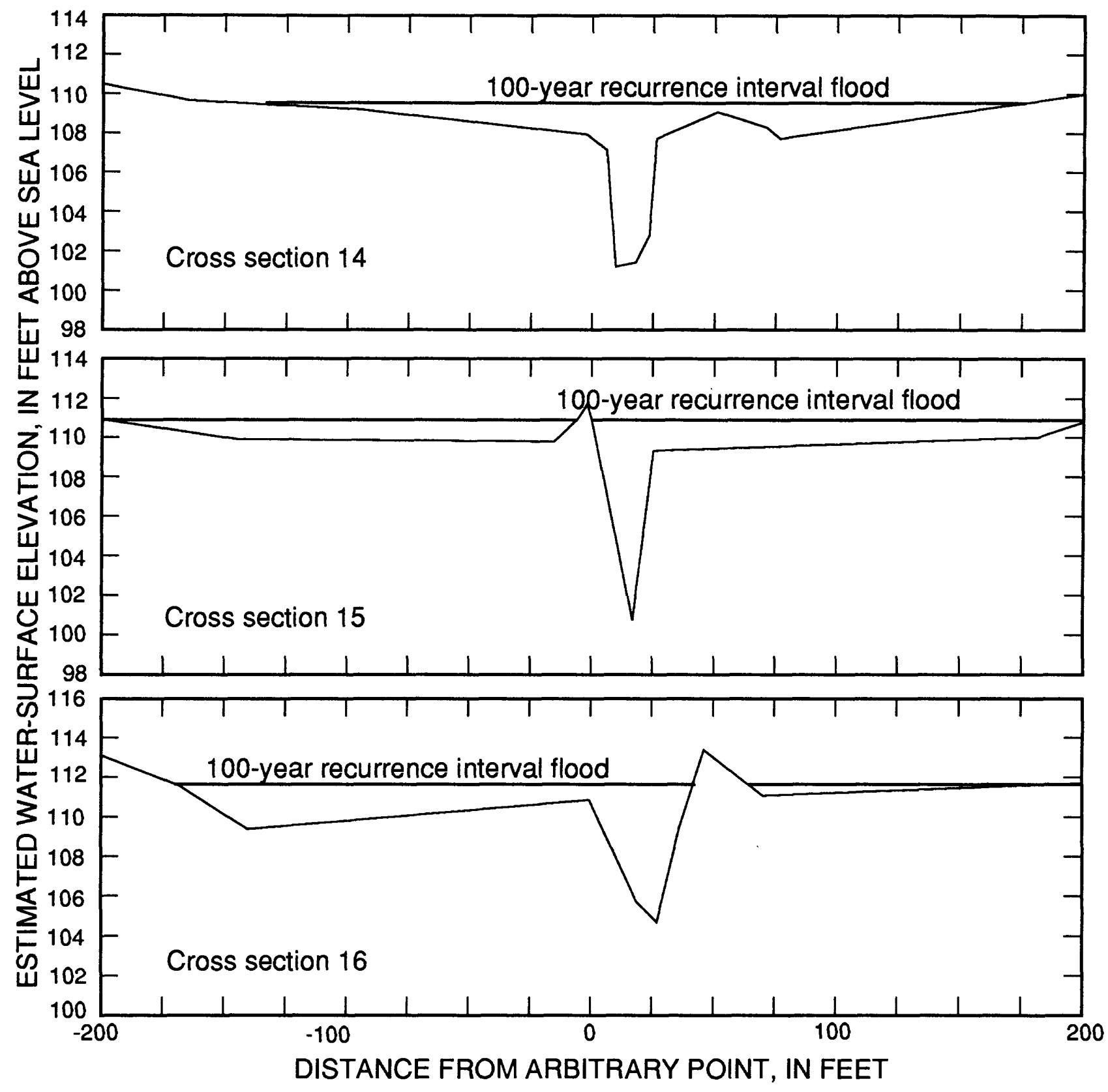

Figure 4. Continued.

Table 2. Estimated water-surface elevations for each cross section

[Elevations are in feet above sea level. $Q_{m e}$, maximum flood experience]

\begin{tabular}{cccccccc}
\hline $\begin{array}{c}\text { Recurrence } \\
\text { interval } \\
\text { (year) }\end{array}$ & 10 & 11 & 12 & 13 & 14 & 15 & 16 \\
\cline { 2 - 8 } & 104.2 & 106.4 & 107.4 & 108.0 & 109.2 & 110.5 & 111.1 \\
25 & 104.7 & 107.2 & 108.1 & 108.6 & 109.5 & 110.7 & 111.2 \\
50 & 104.9 & 107.3 & 108.4 & 108.7 & 109.7 & 110.9 & 111.4 \\
100 & 105.2 & 107.5 & 109.0 & 109.3 & 110.1 & 111.2 & 111.7 \\
$Q_{m e}$ & & &
\end{tabular}


Table 3. Flow magnitude and probability of exceedance for selected recurrence intervals

$\left[Q_{m e}\right.$, maximum flood experience. $\mathrm{ft}^{3} / \mathrm{s}$, cubic foot per second]

\begin{tabular}{cccc}
\hline $\begin{array}{c}\text { Recurrence } \\
\text { interval flood } \\
\text { (year) }\end{array}$ & $\begin{array}{c}\text { Discharge } \\
\left(\mathrm{ft}^{3} / \mathrm{s}\right)\end{array}$ & $\begin{array}{c}\text { Probability } \\
\text { of exceedance } \\
\text { in any year }\end{array}$ & $\begin{array}{c}\text { Probability } \\
\text { of (one) } \\
\text { exceedance } \\
\text { in 100 years }\end{array}$ \\
\hline${ }^{1} 5$ & 500 & 0.20 & 1.000 \\
25 & 1,230 & .04 & .983 \\
50 & 1,600 & .02 & .867 \\
100 & 2,020 & .01 & .634 \\
$Q_{m e}$ & 4,300 & unknown & unknown \\
\hline
\end{tabular}

${ }^{1}$ Flow remains within channel.

\section{MAXIMUM FLOODFLOWS IN CALIFORNIA}

A flood of interest to decisionmakers is the maximum flood experience $\left(Q_{m e}\right)$. Crippen (1979) qualified the maximum flood experience as follows:

"The estimated values of $Q_{m e}$ represent flows that would in many places exceed the capacity of the channels as they now exist. When such extreme flows occur they defy hydraulic analysis for two principal reasons: The channels themselves are altered by erosion and deposition; and backwater effects cause water to leave the normal channels. Some of the overflow may return to the original channel at downstream points, but if topography and erosion permit, new channels may be formed which in some cases may not rejoin the original channel within the area of study. Therefore, the estimates of quantities and mean velocities for extreme flows have little practical value. They represent potential hydrologic input to the point of interest, but the physical bounds of the channel are overwhelmed, and new, unpredictable, situations are created. Even though magnitudes of estimated maximum flow are shown and theoretical elevations reached at the cross sections are indicated, it is not possible to show the potential hazard areas that correspond. Conditions leading to the occurrence of $Q_{m e}$ would be so severe that landslips, extreme erosion, and sheetflow of water and debris would be widespread, even where distinct channels do not now exist."
Maximum flood experience $\left(Q_{m e}\right)$ for a given drainage area was studied and regional curves developed for 17 regions in the conterminous United States (Crippen and Bue, 1977). Region 17, which includes most of California, extends from Baja California to Canada. A review of the curves and 14 years of additional data led to the conclusion that a refinement of the original work was desirable.

The highest recorded peak flows were obtained from 1,296 gaging stations in California and were used to estimate the magnitude of high flood discharges that may occur at a given site on a stream course. The peaks of record were plotted relative to drainage area and a smooth enveloping curve that provides a graphic representation of the $Q_{m e}$ was developed (fig. 5). There is no specific frequency associated with the curve, but it gives evidence to the magnitude of flow that has occurred within a region. The curve is similar in shape to, but different in magnitude from, that of Crippen and Bue (1977) for region 17. The area of California for which the graph/equation applies is shown in figure 6 .

Of the 1,296 maximum peaks studied, 32 were outliers or extreme outliers when compared to the overall mass of the data cloud. These 32 peaks were reviewed carefully; 13 were not used in the final analysis. Five of the 13 peaks were determined to have invalid indirect measurements caused by debris flows or debris dam failures. Three were determined to have incorrect drainage areas; three were based on extremely poor indirect measurements at exceptionally poor sites; and two were due to dam failure.

Equations can be formulated that describe envelope curves below which maximum flood discharges $\left(Q_{m e}\right)$ lie when they are plotted relative to their drainage area $(A)$. For drainage areas greater than $1.0 \mathrm{mi}^{2}$, the equation developed is

$$
Q_{m e}=10,500 A^{1.13}\left(A^{0.5}+5\right)^{-1.37} \text {, }
$$

where $Q$ is in cubic feet per second and $A$ is in square miles. For drainage areas less than $1.0 \mathrm{mi}^{2}$, use $Q_{m e}$ $=900 \mathrm{~A}$.

The $Q_{m e}$ for Franklin Creek is $4,300 \mathrm{ft}^{3} / \mathrm{s}$. 


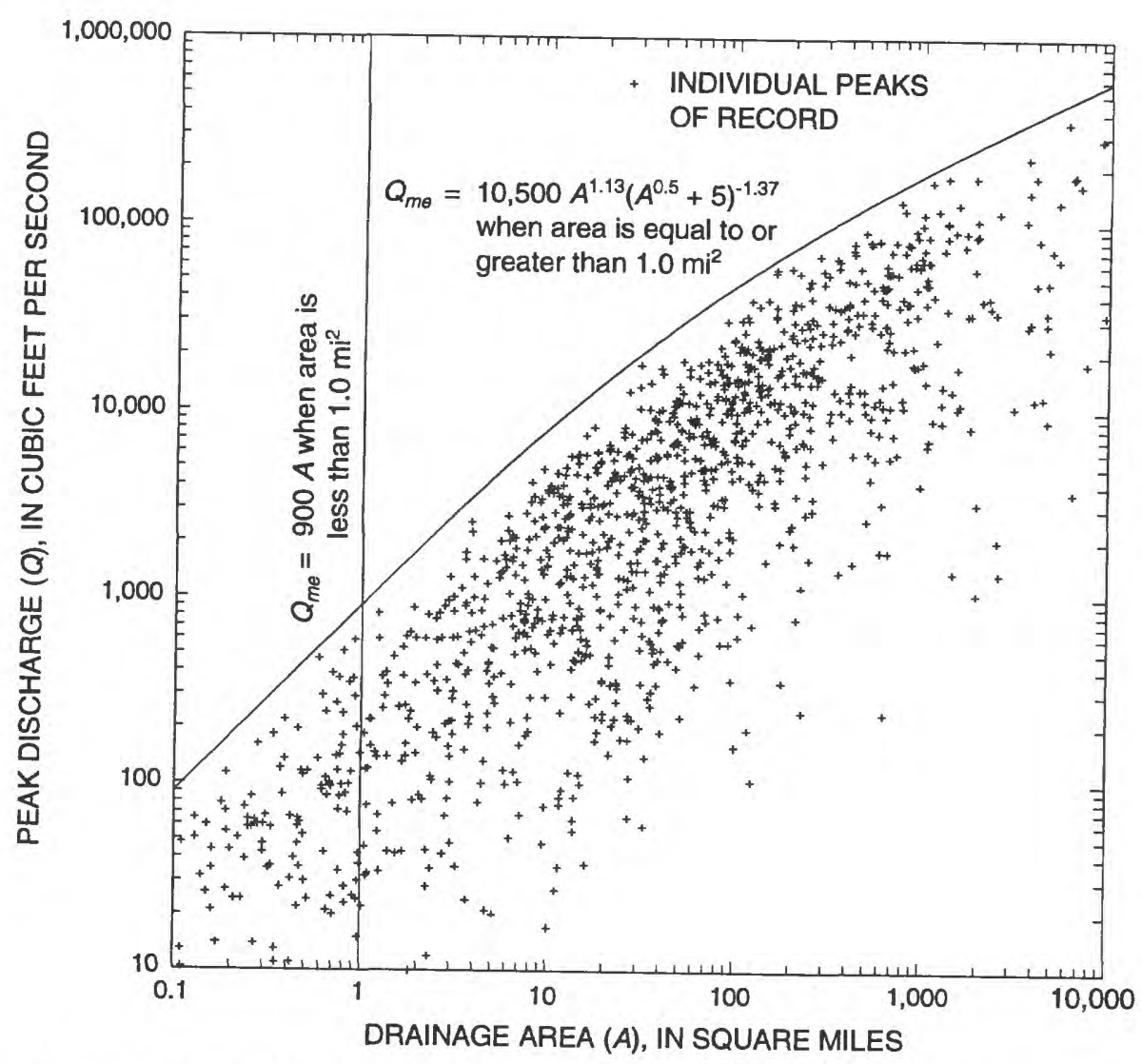

Figure 5. Selected peak discharges and regional envelope curve.

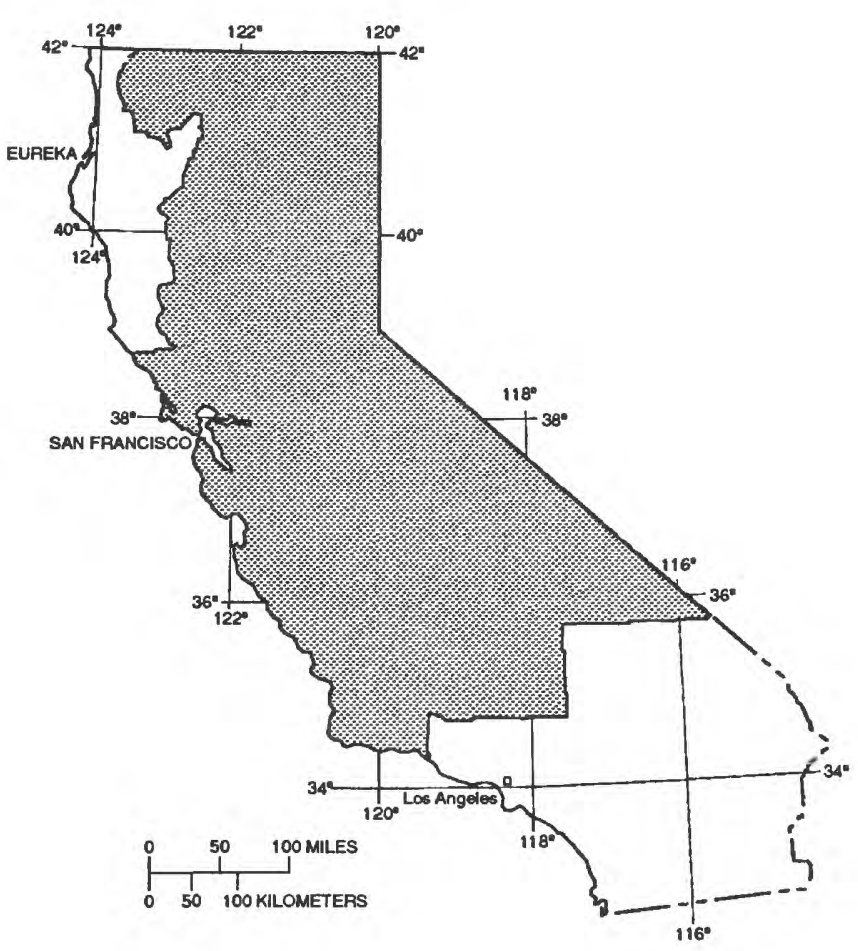

Figure 6. Area of highest recorded peak flows used to estimate $Q_{m e}$.

\section{POTENTIAL HAZARDS FROM FLOODFLOWS AT FRANKLIN CREEK}

Franklin Creek is expected to overflow its banks during all floods greater than the 25-year flood (fig. 2). None of the buildings on the site would be affected by flooding because of their elevations, with the exception of the carriage house near the windmill. The small, single span bridge probably would be inundated by 50 -year or greater floods. The carriage house could be inundated several feet by the 100 -year flood.

All floodflows less than the $Q_{m e}$ will be confined to the orchard and vineyard areas of the site by the small ridge on the eastern one-third of the property. The steel gate in the channel, if closed during a flood, could catch a large amount of debris, locally increase flood elevations, and cause more flooding.

In general, there is little danger to the historically significant structures at the site because they were constructed above the elevations of the 100-year flood. The carriage house could be flooded to a depth of several feet and the orchard and vineyard areas will be inundated. Stream velocities in this area would be relatively slow, with little likelihood of significant damage. 
It is common along the central coast of California for regionwide winter storms to produce most of the precipitation that occurs from November to March. Annual precipitation at the site averages 20.0 in. (Rantz, 1969). Extremely high rates of intense rainfall are rare and flash flooding within the site would be unusual. Flash flooding, however, could occur if landsliding in the upper drainage basin temporarily blocked the channel and subsequently failed. Debris blocking the entrance of the culvert, and subsequently washing out, also could cause flash flooding. In both instances, a large quantity of water could be released downstream without warning.

The Muir House, the Martinez Adobe, and administrative buildings would probably survive a $Q_{m e}$, but the carriage house might be severely damaged. If such a flood did occur, the section of Franklin Creek within the site might not be affected significantly. The large box culvert on the southern boundary is capable of conveying the total flow of the 100 -year flood and would limit a major flood by its capacity to convey part of flows greater than the 100year flood. Maximum discharge would likely be less than $2,800 \mathrm{ft}^{3} / \mathrm{s}$, with excess flow ponding above the culvert entrance and possibly spilling into the Arroyo del Hambre basin. Damage within the site would be similar to that of the 100-year flood. Points of interest on the site would not be affected.

\section{SUMMARY}

Flood magnitudes for given recurrence intervals were determined for the Franklin Creek drainage basin using a drainage-area-ratio method with multiple regression coefficients. Because the discharges exceeded the regional equation results, a verification was made with a unit-hydrograph analysis; agreement was within 5 percent. Water-surface elevations and inundation areas were determined by the stepbackwater hydraulic analysis method.
A review of regional curves developed for the maximum flood experience for a given drainage area with 14 years of additional data led to the conclusion that a refinement of the original work was desirable. Of the 1,296 maximum peaks studied, 32 were outliers or extreme outliers. These 32 peaks were reviewed carefully and 13 were not used in the final analysis.

Franklin Creek is expected to overflow its banks during all floods greater than the 25-year flood. The stream for all floods will be confined to the orchard and vineyard areas of the site by the small ridge on the eastern one-third of the property.

In general, there is little danger to the historically significant structures at the site because they were constructed above the elevations for the 100-year flood. The exception is the carriage house, which could be flooded to a depth of several feet. The orchard and vineyard areas will be inundated. The damage within the site as a result of a maximum flood experience would be similar to that of the 100 year flood.

\section{References Cited}

Crippen, J.R., 1979, Potential hazards from floodflows and debris movement in the Furnace Creek area, Death Valley National Monument, California-Nevada: U.S. Geological Survey Open-File Report 79-991, 23 p.

Crippen, J.R., and Bue, C.D., 1977, Maximum floodflows in the conterminous United States: U.S. Geological Survey Water-Supply Paper 1887, $52 \mathrm{p}$.

Rantz, S.E., compiler, 1969, Mean annual precipitation in the California Region: U.S. Geological Survey openfile report, scale $1: 1,000,000$.

Shearman, J.O., 1977, Computer application for stepbackwater and floodway analyses: U.S. Geological Survey Open-File Report 76-0499, 119 p.

Waananen, A.O., and Crippen, J.R., 1977, Magnitude and frequency of floods in California: U.S. Geological Survey Water-Resources Investigations Report 77-21, $96 \mathrm{p}$. 